\title{
The Influence of TBT on Green Technical Innovation of
}

\section{Chinese Agricultural Enterprise}

\author{
LU Jian ${ }^{1}$, VEMURI S.R. ${ }^{2}$ \\ (1. College of Economics and Trade, Agricultural University of Hebei, Baoding 071001, China; \\ 2. School of Business, Charles Darwin University, Darwin NT 0909, Australia)
}

\begin{abstract}
In recent years, many countries implement the TBT in the export trade practice of agricultural products, which has greatly positive influence on the Chinese agricultural products export enterprise. On the basis of green technical innovation concept, the paper had determined the enterprise green technical innovation motivation mechanism, analyzed the influence of TBT on green technical innovation of the enterprise, and integrated Chinese reality to analyze the influence of TBT on green technical innovation of Chinese agricultural enterprise. Finally, based on the above analysis, the paper proposed corresponding suggestions to the Chinese government.
\end{abstract}

Key words: TBT; green technical innovation; the motive mechanism

\section{Introduction}

TBT is a reality and it requires to be managed domestically. One of the reasons for WTO trade, liberalization and subsequent utilization of TBT is restructuring of the domestics economy. The organization is the "skin" of the domestic economy.

This paper is an examination of how the agricultural enterprise in China needs to respond to the introduction of TBT. Because of the change in trade relationship due to TBT, the paper research on the need for understanding innovations in agricultural enterprise in China.

Through the export trade practice of agricultural products, the TBT fundamentally is the comparative between technique and economy among different countries. The technical standards of import countries express their development of science. By that way they improve their green innovative science. That is just the correct way to overcome trade barriers. Then, what's the influence of TBT on the technical innovation? This is the question that this paper will discuss. The hypothetical condition of the TBT in the realistic trade implements is right and reasonable with the scientific basis. In the third and the fourth part of theoretical analysis, the paper hypothesizes the agricultural products export country is under the perfect market economy condition, has the mature market condition and a certain base of economy, the agricultural products export enterprise has the suitable scale and the strength. In the fifth part of the influence of TBT on green technical innovation of Chinese agricultural enterprise, the paper is based on the situation of the Chinese agricultural products export enterprise.

Through the analysis of the influence of TBT on green technical innovation of Chinese agricultural enterprise,

LU Jian, Ph.D., professor of Economics Department, College of Economics and Trade, Agricultural University of Hebei; research fields: agricultural economy, industrial economy, agricultural information.

VEMURI S.R., dean and associate professor of School of Business, Charles Darwin University, Australia; research fields: macro-economy and labor application, management of environment and natural resource, sustainable development. 
the paper tries to find the reason why the green technical innovation motivation of Chinese agricultural products export enterprise is insufficient, accordingly puts forward the suggestions. This paper uses both the theoretical analysis and the empirical analysis. In the theoretical analysis, the paper has analyzed the influence of TBT on green technical innovation of the agricultural produces export enterprise under the mature market condition, in the empirical analysis, the paper has analyzed the influence of TBT on green technical innovation of Chinese agricultural enterprise and put forward the suggestions to the Chinese government.

\section{The Concept of Green Technical Innovation}

The word of innovation has broad meanings. The important concept of it in economics was advanced by Schumpeter in 1935. He put forward that "innovation is a kind of change of productive function.” It has been many years that the scholars studied. There are many concepts about it ${ }^{1}$. The author of this paper recognizes the view in "The Decision about Strengthening Technical Innovation, Developing High Tech, Realizing Industry". That is the technical innovation including the innovations on products, craft and management ${ }^{2}$.

Green technical innovation is one kind of innovations. According to the introduction above, green technical innovation includes green agricultural innovation, green productive course innovation and green management innovation. The green agricultural innovation means the products will not influence the human health and the environment. And the green productive course means the course will obey the rules of sustainable development. The green management means that under the prerequisite of sustainable development, the management course of benefit of economy, society and ecology with the center of being satisfied with the needs of consumers.

\section{The Motive Mechanism of the Green Technical Innovation of Enterprises}

It has a long history of the study about the new motive mechanism. Before 1980s, it has been divided into two modes. That is about the needs of market or the improvement by the techniques. But after 1980s, there were two patterns existing together, the government policy pattern and the comprehensive pattern proposed by other scholars $^{3}$. These modes attach much importance to the influence of out-factors. It must be related with the theory of economics ${ }^{4}$. Meanwhile, the theory analyzes the conditions of forming the innovative techniques of enterprises

\footnotetext{
${ }^{1}$ The foreign researchers' explanations mainly are: England Freeman described the technical innovation as the steps of technology, design, production, financial, management and marketing campaign which are involved in the process of the first introduction or the innovation products. American scholar Mansfield thought that: the technical innovation is that a new product or a craft is introduced into the market for the first time or is used by the society. Australian scholar Donald Walsh thought that: "The technical innovation is the enterprise carried on the development to the invention achievement, and finally creating the profit through the sale.”

2 In China, the universal approval definition is the definition of the Central Committee of the CCP, the State Council "The Decision about Strengthening Technical Innovation, Developing High tech, Realizing Industry” to the technical innovation: "The technical innovation refers to that applying the innovational knowledge and new technology, the new craft, using the new production method and management, the enterprise improves the products' quality, develops new products, provides the new service, occupies the market and realizes the market value.” Refers to "People's Daily” on August 25, 1999, first edition.

3 The comprehensive pattern mainly has EPNR pattern and so on, E is the enterprise (Enterprise), P is the policy (Policy), $\mathrm{N}$ expresses the need (Need), R expresses the resource (Resource). Refers to: JIANG Xiu-shan, et al. The Study on the Enterprise's Technology Innovation Motive Mechanism. Chinese High-tech Enterprise Appraises, 1999(1).

${ }^{4}$ The enterprise technology innovation theory originates from the western nation. The classical theory is the technical innovation theory proposed by Schumpeter, these theories background on the western perfect market economy society, they have concealed the supposition of economic men. Moreover, in the economic, one of reasonable excess profit origins from the technical innovation, thus the enterprise taking the risk and daring to innovate is the nature performance on pursuing profit maximization, the enterprise technology innovation has the spontaneity, perhaps this is the reason why the above technology innovation motive mechanism attends to condition, neglects the motive.
} 
and the motive of innovative techniques of the enterprises together. Thus lacks of the analysis to the enterprise technical innovation behavior subjective motivation.

This paper will mainly analyze the details about the motives of the innovation of enterprises. And the writer divides the motivations into the interior integrated power and the external integrated power. The interior integrated power includes the subjective motivations and the subjective resistances. And the external integrated power includes the external motivations and the external resistances.

\subsection{The construction of the interior integrated power}

The influence factors of subjective motivation of green technical innovation: (1) The enterpriser's pursuit of profit. (2) The enterpriser's pursuit of innovation. (3) The enterpriser's pursuit of enterprise's credit.

The influence factors of subjective resistance of green technical innovation: (1) Innovation fee. The fee is an extra cost for the enterprises. (2) Innovation risk. (3) Inertial factor. It means that the enterpriser consider the utilization ratio of old resources after the green technical innovation.

\subsection{The construction of the external integrated power}

The external motivation factors are the factors that exist in the external of the enterprise and have some influences on the enterprise. It has the relationships with the subjective motivation factors. These factors can be divided into three kinds: (1) The drive of market's demand. It includes the traction force of market's demand and the pressure of market's competition. (2) The government's influence. (3) The technical stimulation.

The external resistance refers to the factors that restraint the enterprise external motivations. Because of the enterprise external motivations influenced by the regime, resources, culture and industrial development condition, all these factors constituted the limiting condition on the enterprise green technical innovation, namely the external resistance of green technical innovation.

\subsection{The motive mechanism model of the green technical innovation of enterprises}

According to the above analysis, there is a model of this kind in this paper:

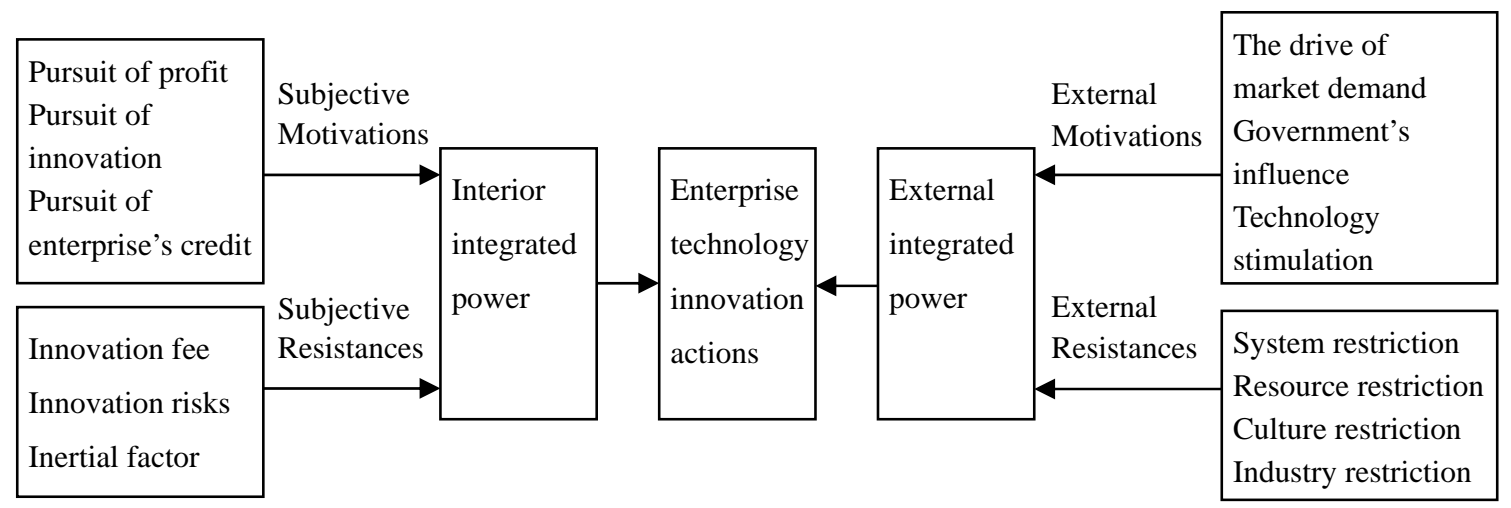

Figure 1 The motive mechanism modes of the green technical innovation

In this model, whether the interior integrated power is positive or negative is decided by the subjective motivations and the subjective resistances, whether the external integrated power is positive or negative is decided by the external motivations and the external resistances. If the motivation is bigger than the resistance, then the integrated power (interior or exterior) is positive, and has the impetus function to the green technical innovation behavior of the enterprise. The sum of the interior integrated power and the external integrated power is the motivation that impetus the agricultural products export enterprise carrying on the green technical innovation, if 
the sum of the interior integrated power and the external integrated power is positive, then the enterprise has the power of carrying on the green technical innovation, if the sum of the interior integrated power and the external integrated power is negative, then the enterprise will not carry on the green technical innovation.

\section{The Analysis on the Influence of TBT on the Green Technical Innovation of Enterprises}

We analyze whether the TBT has influenced the green technical innovation of the agricultural products export enterprise at first. The TBT can limit the import, reduce the Chinese agricultural products export competitiveness directly, and reduce the profit level of the agricultural products export enterprise. The profit is the goal of the enterprises, thus subjectively they have the desires of carrying on the green technical innovation and breakthrough the TBT. Certainly, the enterprises final motive is decided by the TBT to the enterprises' subjective innovation motive and the resistance influence. At the same time, after the import country establishing the TBT, the Chinese government would make a series of reflection. These explain that TBT possibly can change the exterior motive factor of the enterprises' green technical innovation. This can affect the green technical innovation of the enterprise to a certain extent. In brief, the TBT can influence the green technical innovation of the agricultural products export enterprise.

The analysis on the influence of the TBT on the green technical innovation of the agricultural products export enterprise mainly replied a question, namely how does the TBT influence the green technical innovation of the enterprise, has this kind of influence driven or hindered green technical innovation, how intensity does this kind of influence. Unifying above the motive machine-made model of enterprises' green technical innovation, this article analyzes the influences of the TBT to the green technical innovation one by one from the four respects: the subjective motivation, the subjective resistance, external motivation and the external resistance.

\subsection{The influence on subjective motivations}

The TBT refers to the problem of the environment cost internalization ${ }^{5}$. The developed countries believe that the environment cost should be internalized in the export commodities or in the service real cost, in order to promote resources reasonable use and effectively protect the environment, this becomes a reason for them to establish the TBT. Affected by benefit actuation and the country environmental protection backwardness, few of Chinese agricultural products export enterprises consider the problem of environmental protection. Therefore, these enterprises oneself lack of the intrinsic drive on the green technical innovation, only when facing government laws and regulations, technical barriers, market demand pressures, can the enterprise consider the green technical innovation.

Concrete analysis is as follows: Firstly, the import country implementing TBT has made the environment cost internalization and increased the enterprise's cost of operation, driven by the profit maximize, the green technical innovation consciousness of agricultural products export enterprises can be more intense. The enterprise must enhance the product quality, the production efficiency and the profit level through the green technical innovation,

\footnotetext{
${ }^{5}$ The environment cost includes the expense of the production, the packing, the using, the recycling, the processing commodity and paying for the environmental pollution and the destroyed ecology. The interior environment cost theory believes, some export products' production pollutes the peripheral environment, however these environment properties actually often ignore in the national trade, because the export commodity or the service price does not contain or cannot reflect its complete environment cost, the international trade activity causes the market failures to be serious, worsened the environment. Refers to: FU Jing-yan. Environment Cost Intrinsic and Industrial International Competition Strength. China Industry Economy, 2002(6).
} 
alleviate the pressure of the cost; Secondly, along with the developed country universal using TBT, the green consciousness disseminates in the global, the organic food market demand rapidly increases, the organic food has the broad market prospect. Facing above market changing condition, regardless of it from the pursue profit maximization angle or from the pursue innovation angle, agricultural products export enterprises subjectively all have the intense green technical innovation consciousness; Thirdly, on the aspect of pursuing enterprise itself credit, the TBT can bring the environment credit. Producing organic food can strengthen our country agricultural products' competitiveness in international market and enhance the enterprise's repute. Once an enterprise's exported agricultural products break through the import country's TBT, it can obtain the import country's green authentication, this agricultural product could obtain the environment prestige, win consumers' trust, thus promote the agricultural product' export to the import country. In domestic, the enterprises that produce green agricultural products, also can obtain the government' support, consumers' faith, enable the enterprises to have the bigger development superiority. These factors combined action will urge the enterprises to carry on green technical innovation unceasingly, and even more will pay great attention to the enterprises' environment credit.

From the overall analysis, the import country implementing TBT is advantageous to stimulating the subjective motivation of agricultural products export enterprises' green technical innovation.

\subsection{The influence on subjective resistances}

How does the TBT affect the three factors of enterprises' green technical innovation subjective resistance? This paper analyzes it from two aspects: direct influence and indirect influence. The direct influence of TBT to the subjective resistance factor is the negative effect, the concrete manifestation is: Firstly, the establishment of TBT forces agricultural products export enterprises to carry on the green technical development, this has increased the technical invention's cost directly, and caused the increase of the enterprise technical innovation subjective resistance; Secondly, the green technical innovation is also immature, comparing to the ordinary technical, the related knowledge reserve and the technical accumulation about the green technical innovation is relatively short, all these enable it to have the following characteristics: the strong technical, the big difficulty, the big risk and the high operating cost. Moreover, the limited communication increased the risk and the cost about green technical innovation. Specially what worth paying attention to is that the TBT was the import countries' unilateral behavior, the World Trade Organization still cannot well regulate it, there will have the pertinence unavoidably in the process of implementation, flexible also was the common characteristic in the TBT implementation, thus this enables the technical innovation to face a bigger risk, once the innovation succeeds but the technical barriers changes, this could increase the innovation expense once more, moreover could attack the technical innovation confidence of the agricultural products export enterprises seriously; Thirdly, from the aspect of inertia factors, the change and enhancement of TBT makes the green technical knowledge and the technical level which the enterprise pursues to enhance unceasingly, the ordinary staffs are often unable to work because of their limited knowledge. Forcing the agricultural products export enterprises to renew the advanced checker and eliminate tradition checker and so on to the original producer goods abandonment can increase the inertia resistance of the enterprises' technical innovation.

However, the TBT also has the indirect positive influence to the enterprises' innovation subjective resistance. The import countries establishing TBT can stimulate the export state governments to strengthen their export enterprises' technical innovation. The government of export countries can use financial and the industry favorable policy support enterprises' green technical innovation. This may alleviate the funds insufficiency question when the enterprises carry on technical innovation. Adds on the government technical department's technical and the 
information service, the agricultural products export enterprises can grasp more green technical information, enhance their technical innovation confidence, and thus reduce the innovation risk. It is noteworthy that, the positive influence of the TBT to the enterprise subjective resistance depends on government's finance and policy support, the technical service and the information service and so on. Thus, we cannot determine whether the synthesis influences of the TBT on the enterprise green technical innovation subjective resistance are positive or negative.

\subsection{The influence on external motivations}

We analyze the influence of the TBT implementation on the market motive at first. In the agricultural products export enterprises' green technical innovation external motive, the market motive affects most, and the market motive contains the market demand to draw and the market competition actuation. TBT implementation of the import country strengthened the motive of the market demand, and we have already analyzed the organic food market demand condition and the development tendency in the paper above. But the TBT had become the doorsill of the organic food market, transited this doorsill, the agricultural products export enterprises not only can obtain the high profit, but also can obtain the import country consumer's trust, this smooth the way for increasing the market share. When implement TBT, developed countries frequently report agricultural products which are get through the barriers, limited or rejected by the barriers through the media, this kind of report can change the consumer's preference in the very great degree by chance. Under the report's guidance, the consumer can even more trust technical barriers, lose the trust to the agricultural products which does not accord with the standard, thus when the actual purchase, the consumers are partial to the agricultural product which has accorded with the standard. This influence can drive the agricultural products export enterprises to break through the import country TBT with every effort.

\subsection{The influence on external resistances}

The influence of TBT to the green technical innovation external resistance factor is the positive influence. For instance, in order to improve the agricultural products' quality, the country vigorously supports the agricultural products production, the processing and the export, which will be helpful to improve the agricultural development external environment, alleviate the industrial binding force, and promote the related technical innovation. The starting green expenditure and the promoting green culture diffusion will be advantageous to alleviate the cultural binding force. Affected by the TBT, the national related system will also make some changes that are advantageous to enhance the agricultural products export competitive ability, gradually causes the system binding force to change slightly.

\subsection{Synthesis analysis}

We separately discussed the influence of the TBT on the enterprise green technical innovation motive from four angles. From the generalized analysis and Figure 2, we may draw Conclusion 1: when under the market economy condition, it has the mature market condition and the higher economic level of development, the agricultural products export enterprise has the larger scale and the strength, the positive effect of the TBT to the enterprise green technology innovation is bigger than the negative effect. 


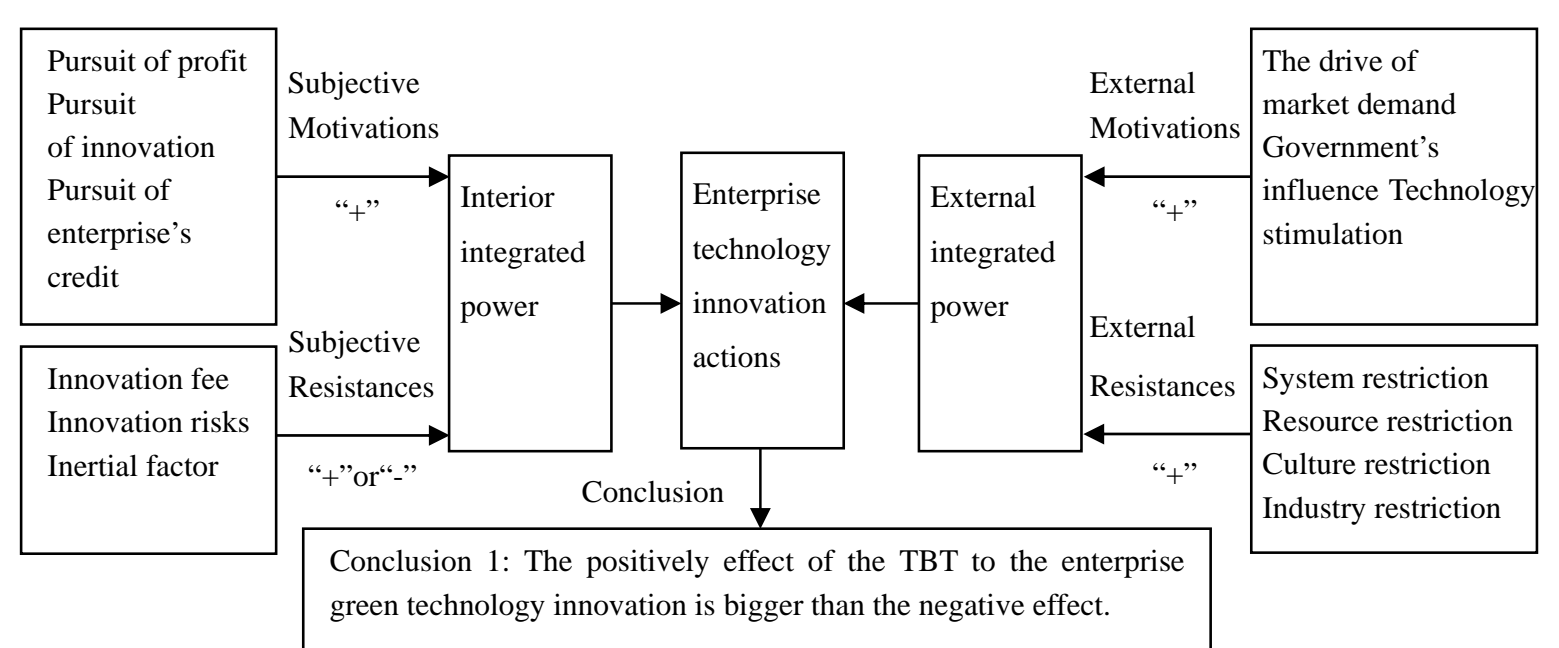

Figure 2 The influence model of TBT to enterprise green technical innovation motive

Note: “+” expresses positive influence; “-” expresses negative effect.

The TBT has the time effect to the green technical innovation drive. The time effect refers to that along with TBT implementation continuing, it stimulates the green technical innovation to gradually increase. This kind of effect comes from: (1) The government's enlarging green technical innovation support dynamics and improving the environment management level form a better external condition for the green technical innovation. (2) The chain-like effect of the government policy. The government implementing a series of technical innovation support policy and environment regulatory policy will impel other policies to make the corresponding adjustment and adaptation, thus it will cause the chain-like effect and will strengthen the policy to stimulate the strength to the green technical innovation in turn. (3) The change of consumer preference. Developed countries implementing the TBT has a certain influence by chance not only to their consumers, but also to the export countries' consumers with the consume preference and ideas along with the time, thus it will form the consensus pressure to the green technical innovation.

\section{The Analysis on the Influence of TBT on Green Technical Innovation of Chinese Agricultural Enterprise}

According to the survey on 22 enterprises of Hebei province that operate the agricultural export products, the export of products exists in the form of "enterprise+peasant household". The peasant households who have certain relationship with the enterprises products according to the demands of the enterprises and the enterprises provide the techniques for the peasant households. And the peasant households who have no relationship with the enterprises just have the business relation. However, the enterprises don't take on the selling responsibility for the peasant households. If the agricultural products don't accord with the standard or the enterprises have not order form, the enterprises will not buy the products from the peasant households. Another way of the export of agricultural products is that the enterprises produce and sell by themselves. In the above two patterns, the principal part is the agricultural products export enterprises in green technical innovation. Because the peasant households are lack of education and their scale of production is limited, so they have no enough motive and ability to implement green technical innovation. So in the following part, the main part of green innovative mechanism is just the agricultural products export enterprises. 


\subsection{The influence on subjective motivations}

At the present stage, most Chinese agricultural products export enterprise' scale is small, lacks of the economic potentiality, so its ability of undertaking the technical innovation risk is low. Implementing the TBT of the import country has some influence on the enterprise technical innovation subjective motivations.

First, the TBT not only greatly increased the enterprise's cost, but also made the product frequently refused by the import country for the reason of failing to the requirement. Most of Chinese agricultural products export enterprises lack for economic potentiality, the ability of undertaking the technical innovation risk is low, moreover the production model "enterprise + peasant household" causes the enterprise unable to carry on the supervision and the control to the course of agricultural products production. Thus, the majority of enterprises give up the import country market facing TBT, refuse to carry on the green technical innovation. Some enterprises even goes out of business because of the increasing TBT of the import country; Second, facing the increasing demand to the organic food, the Chinese agricultural products export enterprise also has the desire of the green technical innovation, but the ordinary enterprise cannot implement the green technical innovation because of its economic potentiality and the technical level; Third, in the aspect of own credit, because the Chinese market credit environment is worse, the ordinary agricultural products export enterprises have little confidence and diligence to their credit.

In brief, the universal problem existing in the Chinese agricultural products export enterprise is that the enterprise lacks for enthusiasm to the green technical innovation facing the TBT, the green technical innovation's subjective motivation is seriously insufficient. The TBT' negative influence is very obvious to the subjective motivation.

\subsection{The influence on subjective resistances}

The negative influence of TBT on the green technical innovation' subjective resistances of the enterprise is as follows: First, the investment of the financial resource, the physical resource and the manpower resource caused by the TBT is a very major difficulty to the Chinese agricultural products export enterprise, which directly increases the green technical innovation's subjective resistances of the enterprise; Second, most of the Chinese agricultural products export enterprise is the middleman, the scale is small and lacks of economic potentiality, the technical level is lower and also lacks for technical innovation accumulation. Moreover the flexible TBT causes great risk to the green technical innovation; Third, looked from the inertia factor, the TBT forces the agricultural products export enterprise to renew the advanced check-equipment and raise worker's technical level in a large scale, all these cause the Chinese agricultural products export enterprise to form the green technical innovation's subjective resistances.

\subsection{The influence on external motivations}

Firstly, we analyze the influence of the TBT on the market motivation. The above paper has already analyzed that the international organic food market demand had giant market potentiality. However, because of the management scale being too small, the farmer cannot adapt the domestic market economy transformation well, cannot adapt the international market. The agricultural products export enterprises are the middle business, they are not responsible to produce, they only purchase and do the simple processing export business to earn profit ${ }^{6}$.

\footnotetext{
${ }^{6}$ In the investigation, we discovered that the majority Chinese agricultural products export corporations are just the "the middle business", their main work is to organize the source of goods for the importers, their basic management idea is "do management on the profit", they scarcely pay attention to the status of our country agricultural products in the import country market, they do not consider how much money our agricultural export products should to be sold, they always decrease the price in the export competition, its result is mutually wounded constantly, not only lets the importer benefit as the third party in a dispute, but also has harmed our country agricultural products image, still possibly initiates the dump lawsuit of the import country.
} 
This situation that the production separates with the export trade, not only causes the farmer to benefit from suffering infraction, but also makes the farmer fail to grasp the international market information and to promptly adjust the products structure and to produce the products which conform to the market demand. The agricultural products export enterprise does not have the ability and the confidence to carry on the technical innovation facing the TBT, thus the agricultural products' quality cannot achieve the import country's request. The developed country, especially Japan, frequently carries on the exaggerating propaganda through the media to the unqualified Chinese agricultural products, causes the consumer to have the prejudice to the Chinese agricultural products, which seriously affects the Chinese agricultural products' image. Thus, the international market demand is difficult to forms the market motivation to the Chinese enterprise's green technical innovation. In domestic market aspect, there is "The lemons market" ${ }^{7}$ phenomenon in the Chinese agricultural products market, which causes the Chinese consumers to use "Adverse selection” ${ }^{\prime 8}$ pattern when they purchase agricultural products, the high quality agricultural products cannot obtain the high price, it causes the high grade agricultural products' production to lack the domestic market demand drawing.

Next, the import country implementing TBT may affect the formulation and implementation of Chinese governmental related policies. It is advantageous for the agricultural products export enterprises to carry on the green technical innovation. In recent years, the increased and strengthened TBT restricted our agricultural products' comparative advantage to transform into the reality competitive advantage. This has already become the significant barrier that restricts Chinese agricultural products export. In view of this situation, the Chinese government departments have formulated the policy and taken the massive measures to promote the green technical innovation and raise the agricultural products processing level. In recent years, the Chinese government has implemented several policy measures in view of the TBT and encouraged the green technical innovation, in which is “Agricultural Products Processing Industry Development Motion Plan” (Ministry of Agriculture on July 29, 2002). The plan proposed the concrete development measure about agricultural products processing industry technical. (1) Formulate and implement the agricultural products processing industry technical advancement plan, clear about goal duty and the work key step, promote our country agricultural products processing industry technical level. (2) The technical advancement plan must take the improved variety cultivation, the production craft innovation, the technical equip research development and application, the bright products maintain freshness research development and application to be the jumping-off point, take the large amount and the export bringing in foreign exchange income products as the key point, according to the research development, the production, the storage and transport, the processing craft, the technical equip and so on to carry on the movements. (3) Fully display the existing scientific research strength, integrate with the present related technical innovation, encourage and support scientific research colleges and universities and the processing enterprises to carry on R\&D together,

\footnotetext{
7 "The lemons market" is originated from the experience name in USA to the substandard goods or the secondhand goods, in 1970, George Akerlof introduced the information economics to carry on the analysis to the second quality item market, and proposed the theory "The lemons market", namely when the product seller has more information to the product quality that the buyer, there will be the reverse choice behavior caused by the asymmetrical products quality information of sellers and buyers, the lower quality product will drive the high grade product out of the market, thus it will cause the continuing decline phenomenon about the market products quality. This theory widely uses in every product market and the hypothesized market analysis.

8 "Adverse selection" refers to that in the situation of business both sides information not asymmetrical, the transaction is obviously difficult compared to the information symmetrical condition, because the information inferiority side must attempt to make the business to be more fairer, in the situation of failing to grasp the commodity quality accurate information, the information inferiority side will choose the bad quality commodity for avoiding being swindled, at last, the bad quality commodity drives the good quality commodity out of the market.
} 
encourage and support the enterprises to establish the R\&D organization and develop new products, new technical, new crafts, and new equipment research. Enjoying the corresponding scientific research and the development support policy if the enterprises independently develop new products and the enterprises and the scientific research do the R\&D together. (4) Enlarge overseas introduction about the advanced technical, the craft, the equipment and the management. (5) Establish and perfect the R\&D project system.

Although these policies and measures are advantageous to the agricultural production's technical innovation and the promotion, because government's fund investment is very little, the concrete measure is difficult to implement in the production practice, then these policies have little influence on the small agricultural products export enterprise.

\subsection{The influence on external resistances}

In the institutional binding force aspect, the Chinese present market economy system is imperfect, especially in the agricultural products market aspect. The market economy system waits for further perfect, thus the TBT has no positive influence on institutional binding force. In the aspects of resources binding force and the industrial development binding force, the country encourages the agricultural industrial development and enhances the resources using in order to improve the agricultural products quality, all these will be helpful to alleviate the resources binding force and the industrial development binding force. The instruction and request of the agricultural products safety in production and consumption will also alleviate the culture binding force in some extent. Thus, although the influence of the TBT on the external resistances is not obvious, the influence is the positive one in the overall.

\subsection{Synthesis analysis}

We separately discussed the influence of the TBT on the Chinese enterprise's green technical innovation motivation. Unifying the Chinese agricultural products export enterprise and Figure 3, we can draw the Conclusion 2: At present stage, the positive influence of the TBT on the Chinese agricultural products export enterprise's green technical innovation is bigger than the negative one. Analyzes its reason: The Chinese market economy system is imperfect at present, there is "the lemons market" phenomenon in the domestic agricultural products market, the majority agricultural products export enterprises’ scales are small, funds is weaker, the antirisk ability is worse.

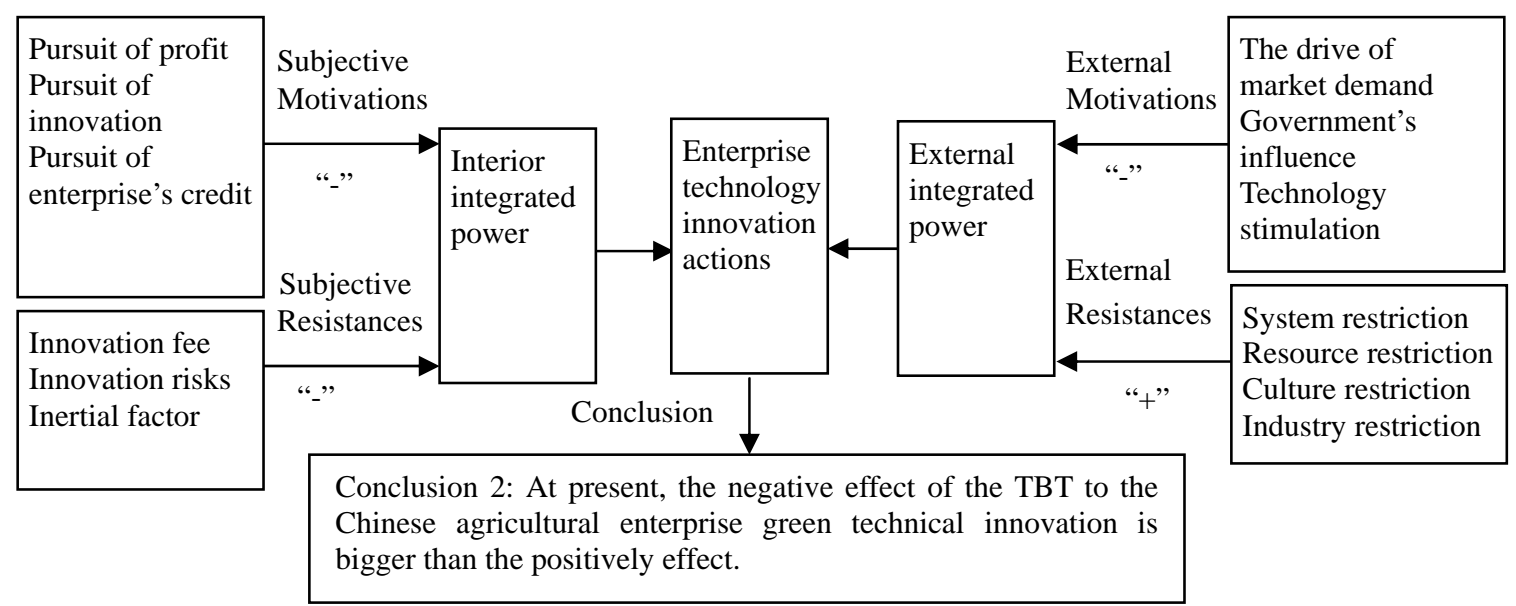

Figure 3 The influence model of TBT on green technical innovation motive of Chinese agricultural enterprise Note: “+” expresses positive influence; “-” expresses negative effect. 


\section{Conclusion}

On the basis of defining, the green technical innovation is the way to enhance the agricultural products export competitive ability, this paper has analyzed the enterprise green technical innovation motive mechanism with emphasis and drawn the conclusions: (1) Under the market economy condition, it has the mature market condition and the higher economic level of development, the agricultural products export enterprises have the larger scale and the ability, and have certain ability of undertaking the scientific research risk, the positively effect of the TBT to the enterprise green technical innovation is bigger than the negative effect. (2) At present, the negative effect of the TBT to the Chinese agricultural enterprise green technical innovation is bigger than the positive one.

To the Chinese government policy suggestions are: First, perfect the Chinese market economy system; Second, construct the domestic agricultural products market environment; Third, cultivate the agricultural products export enterprises' scale; Fourth, afford the essential assistance for the enterprise to breakthrough import countries’ TBT.

References:

[1] Schumpeter J.A.. The Theory of Economic Development. Cambridge: Harvard University Press, 1934.

[2] XU Jian-zhong, WU Yan-yan. Green Management Fundamental Research. Commercial Research, 2004(7).

[3] JIANG Xiu-shan, et al. The Study on the Enterprise Technical Innovation Motive Mechanism. Chinese High-tech Enterprise Appraises, 1999(1).

[4] FU Jing-yan. Environment Cost Intrinsic and Industrial International Competition Strength. China Industry Economy, 2002(6).

(Edited by Jimmy Wang, Gavin Dai and Shirley Hu)

\section{(continued from Page 7)}

What is the tendency for capitalist globalization? Can it be sustained? It must surpass some hurdles as stated by McDonough (2003). There is no doubt that it will not be stable. The most serious attack is the contradiction between the overproduction of world capitalist manufacture system and the weak consumption demand resulting from the suppression of working-class wage. Every fluctuation will bring forth changes in income distribution. However any changes in income distribution must serve for the needs of capital accumulation.

\section{References:}

[1] Stanford, Taylor, Houston. Power, Employment and Accumulation. M.E. Sharpe, 2001.

[2] Frenkel, Kuruvilla. Logics of Action, Globalization, and Changing Employment Relations in China, India, Malaysia, and the Philippines. Industrial and Labor Relations Review, 2002(4).

[3] Terrence McDonough. What Does Long Wave Theory Have to Contribute to the Debate on Globalization. Review of Radical Political Economics, 2003, 35(3): 280-286.

[4] Zafirovsky. Measuring and Making Sense of Labor Exploitation in Contemporary Society: A Comparative Analysis. Review of Radical Political Economics, 2003, 35(4): 462-484.

[5] Richard D. Wolff. The Class Consequences of Colonialism in Africa//ASSA Convention 2001. Reparations, Discrimination and Public Policy. New Orleans, Louisiana.

[6] Memedovic, Kuyvenhoven, Molle. Globalization of Labor Markets. Kluwer Academic Publishers, 1998.

[7] Andre Gunder Frank. Dependent Accumulation and Underdevelopment. Yilin Press, 1999.

[8] Martin, Schuman. The Trap of Globalization. Central Compilation \& Translation Press, 1998.

[9] ZHANG Shi-peng, YIN Xu-yi. Capitalist in Globalization Era. Central Compilation \& Translation Press, 1998.

[10] LI Min-qi. China Social Structure in the Vision of World System. Horizon, 2003, 11(8).

(Edited by Jimmy Wang, Gavin Dai and Shirley Hu) 